\title{
Numerical Analysis on the Performance of High Concentration Photovoltaic Systems Under the Nonuniform Energy Flow Density
}

\author{
Haifei Chen, Yunjie Wang, Yuwei Ding, Baorui Cai and Jie Yang* \\ School of Petroleum Engineering, Changzhou University, Changzhou, China
}

Photovoltaic panels can directly convert solar energy into electricity, but temperature will have a certain impact on the efficiency of photovoltaic cells. Especially under the condition of nonuniform energy flow density of high-power concentration, it is of great significance to maintain the temperature uniformity of cells. Therefore, based on the radiation under nonuniform heat flux density, four heat exchangers were proposed: single-channel serpentine flow, multi-channel flat plate, full jet, and single-jet nozzle. Taking into account the uniformity of the cell temperature, the single-jet nozzle and single-channel

OPEN ACCESS

Edited by:

Mingke $\mathrm{Hu}$,

University of Nottingham,

United Kingdom

Reviewed by:

Bo Li,

Chongqing University, China

Qiongfen Yu,

Yunnan University, China

*Correspondence:

Jie Yang

yj12345@cczu.edu.cn

Specialty section:

This article was submitted to

Solar Energy,

a section of the journa

Frontiers in Energy Research

Received: 06 May 2021

Accepted: 17 June 2021

Published: 08 July 2021

Citation:

Chen H, Wang Y, Ding Y, Cai B and Yang J (2021) Numerical Analysis on

the Performance of High

Concentration Photovoltaic Systems

Under the Nonuniform Energy

Flow Density.

Front. Energy Res. 9:705801.

doi: 10.3389/fenrg.2021.705801 serpentine flow can better maintain the uniformity of the temperature field compared with other heat exchangers. Especially under high-concentration energy flow density, considering the quality of heat and electricity, the performance of the four-jet nozzles is the best from the perspective of exergy efficiency. Under the condition of four-jet nozzles, the electrical efficiency and thermal efficiency of the cell can be maintained at about 29 and $62.5 \%$, respectively, and the exergy efficiency of the system can reach $31 \%$.

Keywords: solar energy, high concentration ratio, nonuniform flux, thermal performance, CFD simulation

\section{INTRODUCTION}

Recently, the serious environmental pollution of fossil fuels and mining life problems have become important factors affecting climate change and economic development (He, et al., 2021). As the world's energy structure transitions to green and low-carbon, domestic and foreign scholars and experts are exploring more new types of energy. As a clean, abundant, and renewable new energy, solar energy stands out from many alternatives, and has now been widely used in construction, transportation, communications, petroleum, and other fields (Dirker, et al., 2019; Leonard, et al., 2020; Singh, 2021). Compared with other new energy sources, such as wind energy and geothermal energy, solar energy has the characteristics of being more flexible and adaptable. Although solar energy is restricted by geographical factors, it still has broad development prospects.

Photovoltaic power generation is one of the main application methods of conventional solar power generation. It is basically composed of solar cells in series and parallel to form photovoltaic modules, and then is made to cooperate with the controller and inverter to generate electricity (Lakshmi Swarupa et al., 2021). On this basis, concentrated photovoltaic power generation adds an optical device that condenses solar energy on the surface of the photovoltaic module, which greatly reduces the expensive cost caused by the use of semiconductor materials (Gakkhar, et al., 2020). Among them, low concentration photovoltaic (LCPV), such as V-groove concentrators, require relatively low operating and maintenance costs because they do not require solar trackers and have 
simple technical requirements. At the same time, they can also provide a certain energy output when applied to non-energy buildings (Parupudi, et al., 2020). When LCPV systems are used in the field of seawater desalination, studies have shown that the total output of fresh water will increase significantly during the day, and the solar radiation intensity can effectively improve the thermal efficiency of the system (Xinxin, et al., 2019). Through software simulation, it can be known that considering the factors of incident angle and concentration ratio, different degrees of deformation of the compound parabolic concentrator (CPC) will have a certain impact on the CPC concentration (Xu, et al., 2018). Research on the parabolic trough solar collectors shows that the use of integrated power generation and cooling units can relatively improve thermal efficiency and power generation efficiency, and it is also outstanding in terms of cost reduction (Habibollahzade, et al., 2018). Due to the relatively high power and economic benefits of high concentration photovoltaic (HCPV) systems under actual weather conditions, the current concentration photovoltaic designs are developing to a higher concentration level (Shanks, et al., 2018). After adding a circular Fresnel lens in the middle of the traditional Fresnel condenser, as the solar radiation intensity increases, the thermal efficiency of the system will be significantly improved (Liang, et al., 2021). Recently, linear Fresnel solar reflectors have also been used in polygeneration energy systems to replace traditional fossil fuels to provide power (Sun, et al., 2021).

In view of the uneven distribution of light in the concentration system, a suitable front metal index and its spacing can enhance the performance of low-concentration photovoltaic cells ( $\mathrm{Li}$, et al., 2020). A study shows that when the wind speed is less than a certain value, the heat dissipation performance of the highconcentration solar cell module is significantly affected by the wind speed (Wang, et al., 2013).

When the uniformity of light on the surface of the cell is poor, stronger solar radiation intensity will more easily increase the surface temperature of the photovoltaic cell, thereby reducing the photoelectric conversion efficiency (Saura, et al., 2021). This is mainly because the increase in temperature will reduce the open circuit voltage of the battery, so in order to obtain the required output power, the cell is required to have a larger load. Therefore, the effective heat dissipation of photovoltaic cell, especially for highpower concentration systems, is indispensable and worthy of discussion and research (Hernandez-Perez, et al., 2021). Regarding how to determine the surface temperature of photovoltaic cells, Eduardo F. et al. (Fernandez, et al., 2014) analyzed and compared four methods for estimating the temperature of cells, indicating that the module-based direct measurement is better.

The cooling technology of photovoltaic cells includes active cooling and passive cooling. In some cases, passive cooling is not enough to meet the cooling requirements of the system, especially for high-power concentration systems with larger energy density, the use of active cooling will be better (Siah Chehreh Ghadikolaei, 2021). In plate heat exchangers, mutually parallel and straight metal plates are usually used to evenly distribute the heat transfer fluid in many narrow channels to flow, and a more novel way is to use serpentine coils to guide the fluid flow path (Arvanitis, et al., 2020). One study has shown that the serpentine tube structure extends along the length of the cooling plate, and can obtain a better cooling effect than the width direction. At the same time, reducing the coolant temperature is the best way to improve cooling efficiency (Deng, et al., 2018). In the research of a new type of solar air heater, it was found that improving the heat transfer efficiency of the current collector mainly depends on increasing the length of the current collector (Hajabdollahi, 2021). A study has shown that the rectangular protrusions on the solar heat exchanger absorber can obtain better hydraulic and thermal performance, and at the same time increase a certain amount of friction loss (Kumar, et al., 2021). In terms of selecting the working fluid, nanofluid has a great potential in the application of cooling PV panels due to its high thermal conductivity and good optical properties (Al-Shamani, et al., 2014; Qeays, et al., 2020). For plate heat exchangers that use nanofluids as working fluids, it has shown that $\mathrm{Fe}_{3} \mathrm{O}_{4}{ }^{-}$water nanofluids have great prospects in improving thermal performance (Zheng, et al., 2020). Jet impingement cooling technology is a kind of active cooling, which can not only maintain the low temperature of the cell under highconcentration solar energy conditions, but also the power consumption of the device is less than $1 \%$ of the cell's power generation (Abo-Zahhad, et al., 2018). The hybrid cooling method that combines jet impingement cooling and microchannel cooling is very helpful for improving cell temperature uniformity on the basis of enhancing the cell cooling effect (Abo-Zahhad, et al., 2019). Generally, the cooling stability of a single jet is worse than that of multiple jets. At the same time, the increase of the distance between the two jets will reduce the energy loss of the jet itself, thereby improving the thermal performance of the system (Nadda, et al., 2018).

Although a lot of research work has been done on HCPV systems, there is little research on the performance of the system under the nonuniformity of heat flow density coupled with the nonuniformity of temperature field. In this study, under the condition of uneven and high heat flux, four kinds of heat exchangers were combined with concentration photovoltaic cells to study the cells' uniformity of temperature, thermal, and electrical performance. For four different exchanger structures, a comprehensive three-dimensional model was established. The influence of different energy flow densities and mass flow on the temperature of cell, electrical efficiency, and thermal efficiency was studied. Furthermore, an exchanger structure that can better maintain cell temperature uniformity under the condition of uneven and high heat flux density is proposed. In addition, the comprehensive performance of the exchanger with the best temperature uniformity is analyzed from the perspective of thermodynamics, which can be used for industrial printing and dyeing, domestic water, and so on.

\section{Physical Model}

In order to carry out this research, a typical HCPV system was analyzed, which can be seen from Figure 1. The whole system includes a high-power concentrator, a solar concentrating photovoltaic cell, a solar concentrating photovoltaic cooling heat exchanger, a solar tracking device, and a hot water storage tank. The concentrator is used to concentrate the solar irradiance on the solar cell, and the exchanger takes away the excess heat of the solar cell. In this system, a two-dimensional 


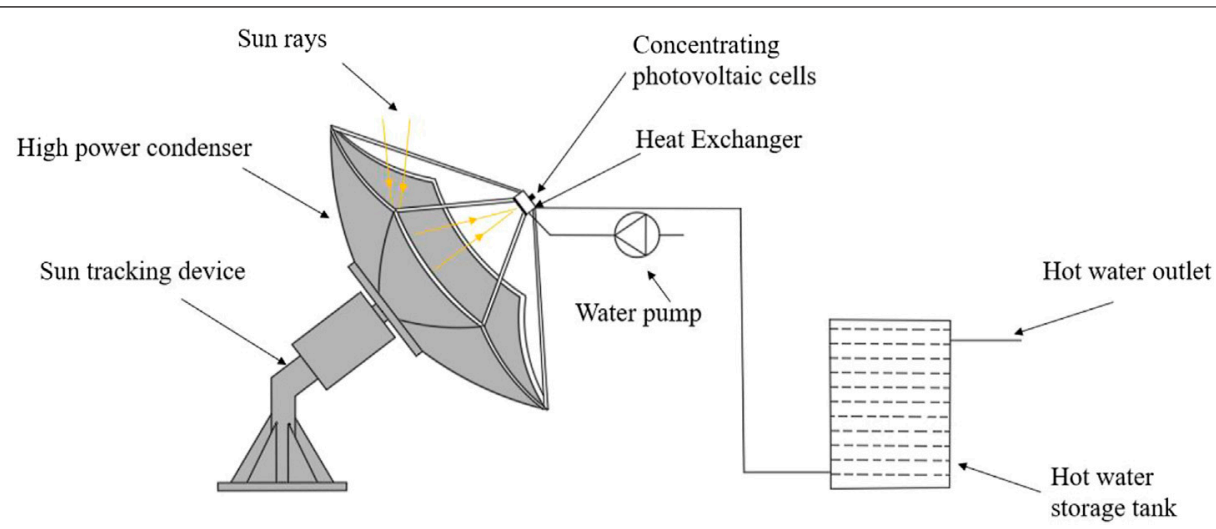

FIGURE 1 | A typical high-power concentrator system.
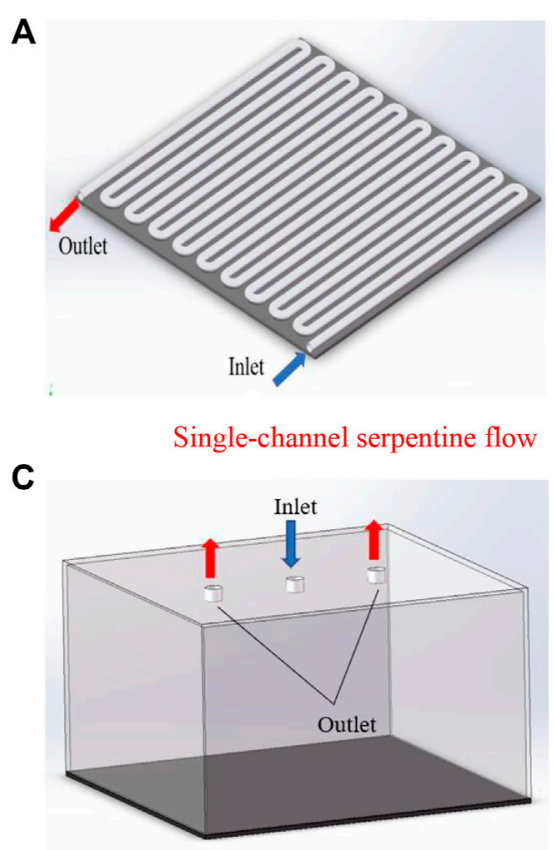

Full jet
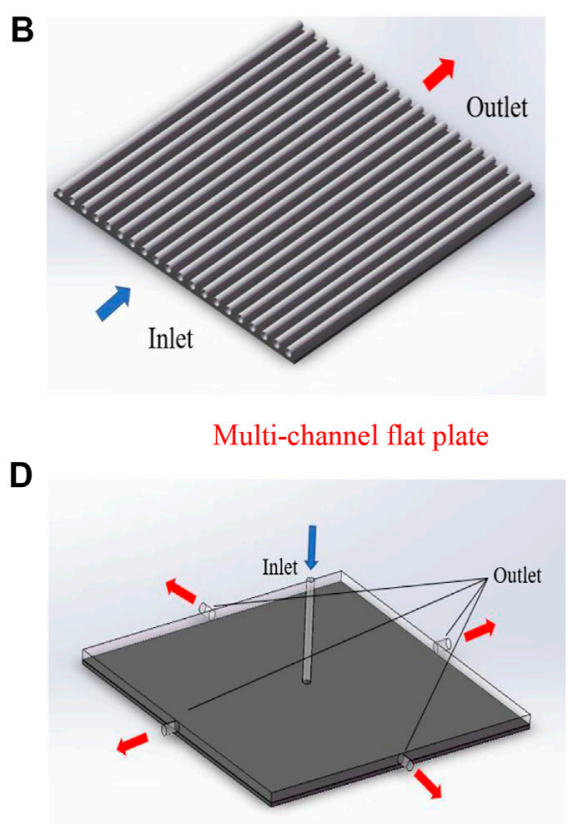

Single-jet nozzle

FIGURE 2| Four different solar concentration photovoltaic cooling heat exchangers. (D) Single-jet nozzle.

tracking device is used. The two-dimensional tracking device can always make the sunlight incident perpendicularly to the concentrator, and then gather it to the solar concentrating photovoltaic cell located on the focal plane through the reflective surface, which can achieve a concentration ratio of more than 500. The solar concentrator cell in this study uses triple junction GaAs, and the size of the heat exchanger is $20 \times 20 \mathrm{~cm}$.

The working performance of solar concentration photovoltaic cells depends not only on the concentration ratio, but also on the working temperature. If the working temperature of the cell is poor, it will affect its electrical efficiency and even its working life. Studies have shown that the optimal operating temperature range of a solar concentration photovoltaic cell is $25-80^{\circ} \mathrm{C}$. If the temperature exceeds $110^{\circ} \mathrm{C}$, the service life of the cell will be affected (Aldossary, et al., 2016). Therefore, the exchanger should be combined with the solar cell to take away the excess heat. As shown in Figure 2, four different solar concentration photovoltaic cooling heat exchangers are combined with the cell to compare the performance parameters of the cells. It can be seen from Figure 2 that the four heat exchangers are single-channel serpentine flow, multichannel flat plate, full jet, and single-jet nozzle, which reflect the heat exchange of photovoltaic cells by the water-cooled enhanced heat exchange method from different angles. In addition, the specific parameters of the heat exchanger structure are shown in Table 1. 
TABLE 1 | Specific parameters of the simulated heat exchanger.

\begin{tabular}{lcc}
$\begin{array}{l}\text { The structures of } \\
\text { the heat exchanger }\end{array}$ & $\begin{array}{c}\text { Dimensions } \\
\text { of inlet } \mathbf{( m m )}\end{array}$ & $\begin{array}{c}\text { Dimensions } \\
\text { of outlet }(\mathbf{m m})\end{array}$ \\
\hline single-channel serpentine flow & $5 \times 5$ & $5 \times 5$ \\
multi-channel flat plate & $5 \times 5 \times 20$ & $5 \times 5 \times 20$ \\
full jet & $5 \times 5$ & $5 \times 5 \times 2$ \\
single-jet nozzle & $5 \times 5$ & $5 \times 5 \times 4$ \\
\hline
\end{tabular}

\section{THEORETICAL AND SIMULATED ANALYSIS}

\section{Theoretical Analysis}

In the model of this study, after considering optical losses, the energy that actually reaches the photovoltaic surface is converted into a nonuniform heat flux. For the thermal energy $Q_{p v}$ generated by the photovoltaic cell in the process of absorbing solar energy, it can be obtained by the following formula:

$$
Q_{p v}=\alpha_{p v} G A_{p v}-E_{p v},
$$

where $\alpha_{p v}$ is the absorption rate of the photovoltaic cell, $G$ is the total energy reaching the surface of the photovoltaic cell $\left(\mathrm{W} / \mathrm{m}^{2}\right)$, which is related to solar radiation and concentration ratio, $A_{p v}$ is the area of the photovoltaic cell $\left(\mathrm{m}^{2}\right)$, and $E_{p v}$ represents the power output of the photovoltaic cell (W).

The output power $E_{p v}$ of the photovoltaic cell is affected by the total amount of direct solar radiation that reaches the surface of the cell after being collected by the concentrator and the photovoltaic cell temperature $T_{p v}$, which can be calculated by the following formula:

$$
E_{p v}=r_{p v} A_{p v} G \eta_{p v}
$$

where $r_{p v}$ is the coverage factor of photovoltaic cells and $\eta_{p v}$ is the photoelectric conversion efficiency of photovoltaic cell.

The working electrical efficiency of the cell is a function of the working temperature and the efficiency of the solar cell at the reference cell temperature, which can be calculated by the following formula (Maka and O'Donovan, 2020):

$$
\eta_{p v}=\eta_{\text {ref }} \times\left[1-\beta \times\left(T_{\text {cell }}-T_{\text {ref }}\right)\right],
$$

where $\eta_{r e f}$ and $T_{r e f}$ are the electrical efficiency and temperature of the photovoltaic cell under reference conditions, respectively, with the value of $\eta_{\text {ref }}$ at $32 \%$ and the value of $T_{\text {ref }}$ at $25^{\circ} \mathrm{C}, T_{\text {cell }}$ is the working temperature of cell $\left({ }^{\circ} \mathrm{C}\right)$, and $\beta$ is the thermal coefficient.

The formula of the thermal efficiency of the system is as follows:

$$
\eta_{\text {th }}=\frac{Q_{w}}{A \times G}=\frac{m \times c_{p} \times\left(t_{\text {out }}-t_{\text {in }}\right)}{A \times G},
$$

where $\eta_{t h}$ is the thermal efficiency of the photovoltaic cell, $Q_{w}$ is the heat energy output by the system (W), $m$ is the mass flow of cooling fluid $(\mathrm{kg} / \mathrm{s}), A$ is the area of the entire surface $\left(\mathrm{m}^{2}\right)$, $c_{p}$ is the specific heat capacity of the cooling fluid at constant pressure $\left(\mathrm{J} \cdot \mathrm{kg}^{-1} \cdot{ }^{\circ} \mathrm{C}^{-1}\right), t_{\text {in }}$ is the inlet temperature of the cooling

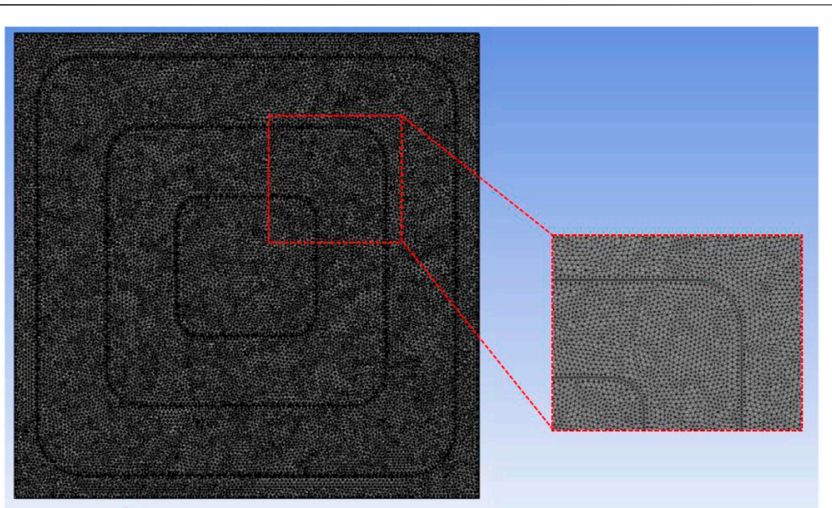

FIGURE 3 | Area divisions and grids of the surface of the heat exchanger.

fluid $\left({ }^{\circ} \mathrm{C}\right)$, and $t_{\text {out }}$ is the outlet temperature of the cooling fluid $\left({ }^{\circ} \mathrm{C}\right)$.

In order to further explore the comprehensive performance of the system, the comprehensive efficiency proposed according to the first law of thermodynamics is used to evaluate, which is equal to the sum of electrical efficiency and thermal efficiency. The formula is as follows (Khanjari, et al., 2016):

$$
\eta_{\text {total }}=\eta_{\mathrm{th}}+\eta_{\mathrm{pv}}
$$

where $\eta_{\text {total }}$ is the overall efficiency.

However, the comprehensive efficiency proposed only based on the first law of thermodynamics is one-sided. Therefore, from the analysis of the second law of thermodynamics, the exergy efficiency is proposed to better evaluate the comprehensive performance of the system. Exergy refers to the part of energy that can be converted into useful work when the system interacts with the environment, which reflects the quality of energy to a certain extent. The formula is as follows (Aste, et al., 2015):

$$
\eta_{e l}=\eta_{p v}+\eta_{t h}\left[1-\frac{T_{s}}{T_{\text {out }}-T_{s}}\right]
$$

where $\eta_{e l}$ is the exergy efficiency, $T_{s}$ is the temperature of the environment $(\mathrm{K})$, and $T_{\text {out }}$ is the outlet temperature of the cooling fluid $(\mathrm{K})$.

\section{Meshing and Grid Independence}

Under the condition of uneven high-power concentrated energy flow density, the distribution of energy reaching the heat exchanger is also uneven, with a certain range of attenuation from the center to the edge. In order to give uneven heat flux density on the surface of the heat exchanger, a model was built using ANSYS software, the surface was divided into different regions, and the mesh was drawn in Meshing, which can be shown in Figure 3. For the cell to obtain more uniform heat flow, the size of the cell should be similar to the innermost area in Figure 3.

At the same time, in order to simplify the calculation and improve the feasibility of the simulation and the correctness of 


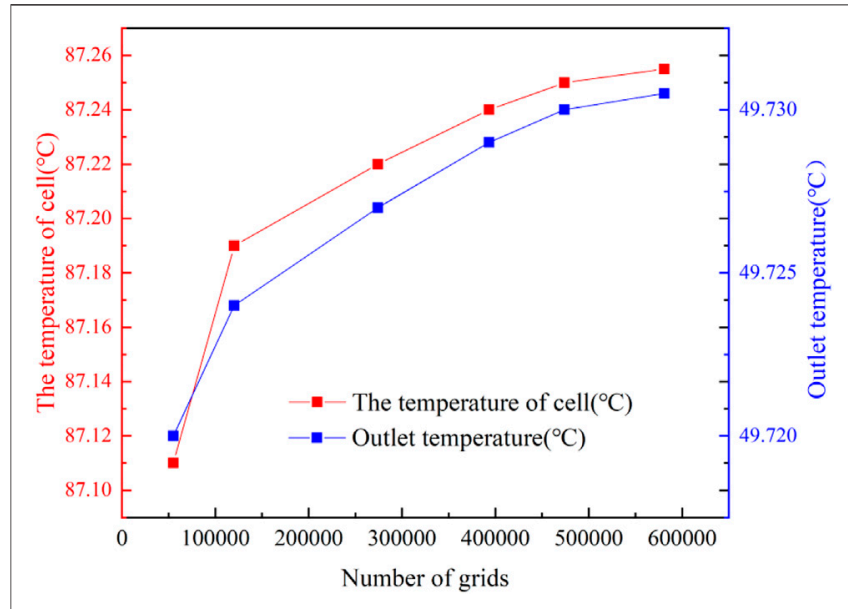

FIGURE 4 | Temperature of the cell and outlet temperature under different grid numbers.

the simulation results, the following assumptions were made during the numerical simulation:

1) The cooling fluid is an incompressible fluid, its physical parameters are constant, and there is no slippage on the wall of the model;

2) There is no dust on the surface of the photovoltaic cell;

3) The transmittance of the EVA layer is 1 ;

4) There is perfect thermal contact between the photovoltaic cell and the bottom copper substrate;

5) The thermophysical properties of the solid domain have nothing to do with temperature.

In order to simulate and calculate the established heat exchanger model, it is necessary to verify the grid independence. As shown in Figure 4, taking a singlechannel serpentine flow as an example, the simulation results of six different grid cell numbers of 55,089, 120,312, $273,991,393,126,473,991$, and 580,863 are compared. It can be seen from Figure 4 that the temperature of the cell and the outlet water temperature calculated by the number of grids of 473,991 and 580,863 are not very different, and the relative error is about $0.0057 \%$. Taking into account the cost of calculation, continuing to refine the grids is of little significance to the output results. Therefore, the number of grids selected in this study is 473,991 .

\section{RESULTS AND DISCUSSION}

\section{The Influence of Different Heat Exchanger Structures on the Temperature Uniformity of Cell}

Figure 5 shows the temperature field distribution of the cells under four heat exchangers. Under the same mass flow and heat flow density, the temperature field of the cell combined with the single-channel serpentine flow heat exchanger is relatively uniform, and the cooling fluid takes away a lot of heat. However, the temperature field of the cell has a certain increase from the inlet to the outlet, which is not obvious. The temperature field of the cell combined with the multi-channel flat plate heat exchanger is uneven and obviously distributed in stripes. The temperature of the part in contact with the channel is less than $80^{\circ} \mathrm{C}$, and the noncontact part does not lose a lot of heat, which exceeds $80^{\circ} \mathrm{C}$. Under the action of high heat flux density, the temperature difference of the cell between the area where the cooling fluid passes and the area without the cooling fluid will be very large and long-term operation will affect the service life of the cell.

Figure 5C and Figure 5D are the temperature field distributions of the cell under full jet and single-jet nozzle, respectively. Compared with the first two forms, the two structures can keep the temperature uniformity in the high heat flux in the center, and the uniformity of the single-jet nozzle is better than that of the full jet. Compared with the single-channel serpentine flow and the multi-channel plate, the average temperature of the cell exceeds $80^{\circ} \mathrm{C}$, which is suitable for medium-fold energy flow density. It can be seen from Figure 5 that the single-channel serpentine flow and single-jet nozzle can better maintain the uniformity of the cell temperature field.

\section{The Influence of Inlet Flow on the Uniformity and Temperature of Cell}

Figure 6 and Figure 7, respectively, show the influence of the inlet flow on the average temperature of the cell with different concentration ratios. For single-jet nozzle, as the flow rate increases, the temperature of the cell has a downward trend, but as the concentration ratio increases, to ensure that the temperature of the cell is in a safe area, the range of the flow rate will be reduced. When the inlet flow is more than $0.08 \mathrm{~kg} / \mathrm{s}$, the heat taken away by the cooling liquid is not enough to quickly reduce the temperature of the cell, which is suitable for a low concentration ratio of 100 . Especially in the dish-type concentration system with nonuniform heat flux, when the concentration ratio exceeds 500, no matter how large the inlet flow is, it is not enough to ensure the effective working temperature and temperature uniformity of the cell. Therefore, under the existing cooling method, the concentration ratio of the dish system is recommended to be less than 500 .

Compared with the single-jet nozzle, the single-channel serpentine flow can carry a lot of heat, thereby the temperature of the cell will drop sharply, especially when the inlet flow rate changes from $0.04 \mathrm{~kg} / \mathrm{s}$ to $0.18 \mathrm{~kg} / \mathrm{s}$. When the inlet flow exceeds $0.18 \mathrm{~kg} / \mathrm{s}$, the temperature changes more slowly, which has less influence on the temperature of the cell. And when the concentration ratio is 500 , the system under singlechannel serpentine flow can also work normally. Therefore, single-channel serpentine flow is more suitable for a highpower concentration system than single-jet nozzle.

Figure 8 shows the temperature difference of cells between the single-channel serpentine flow and single-jet nozzle 
A

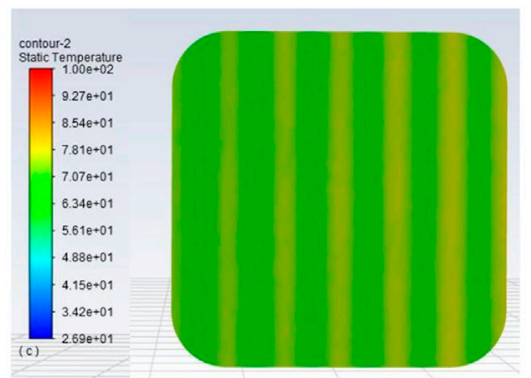

Single-channel serpentine flow

C

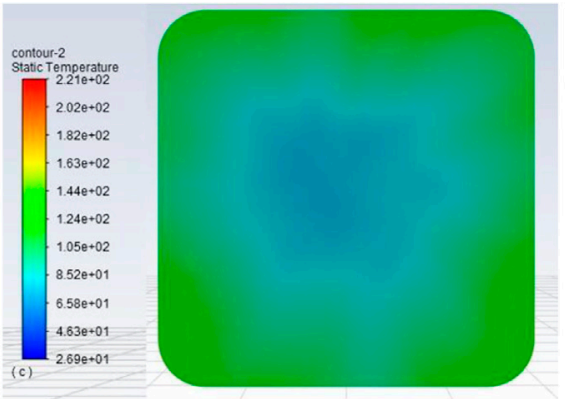

Full jet
B

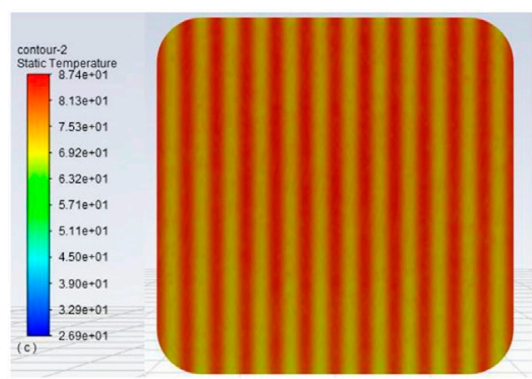

Multi-channel flat plate

D

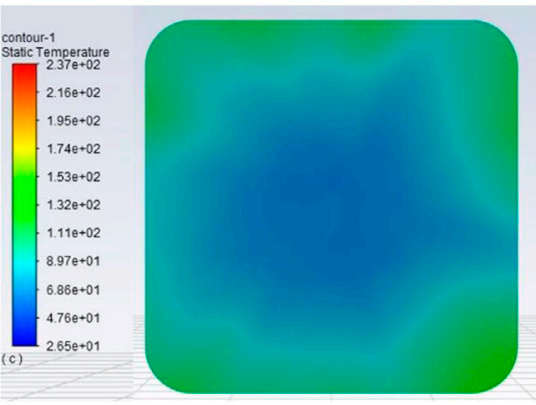

Single-jet nozzle

FIGURE 5 | Temperature field distribution of the cell under four different conditions, the Influence of inlet flow on the uniformity and temperature of the cell. (A) Single-channel serpentine flow; (B) Multi-channel flat plate; (C) Full jet; and (D) Single-jet nozzle.

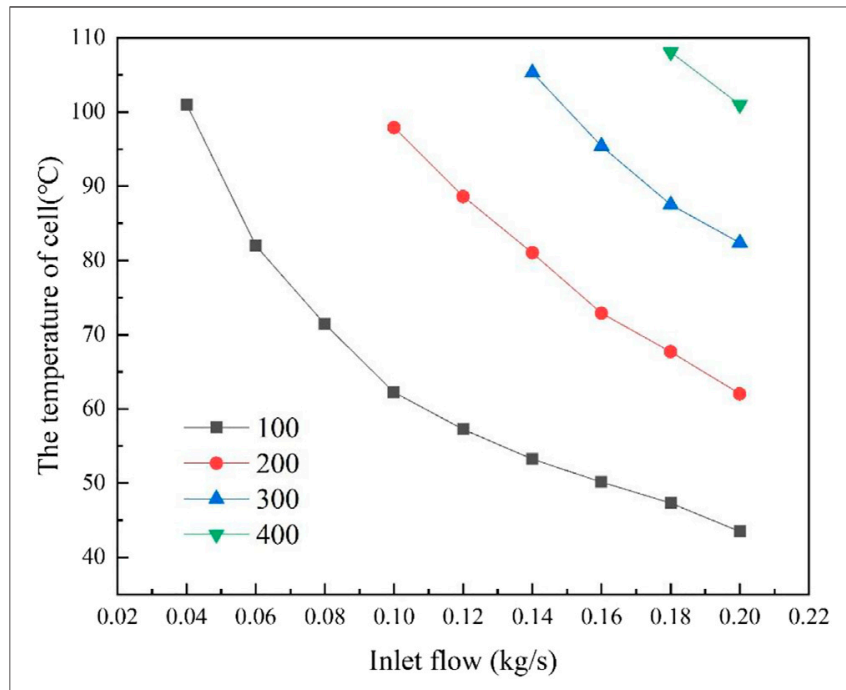

FIGURE 6 | Influence of inlet flow on the temperature of the cell under the single-jet nozzle.

under the energy flow density of the concentration ratio of 100. As the flow increases, the temperature difference in cell decreases. When the inlet flow is less than $0.1 \mathrm{~kg} / \mathrm{s}$, the cell temperature difference under the single-channel serpentine flow is smaller than that under the single-jet nozzle. If the flow rate further increases, the temperature field of the cell

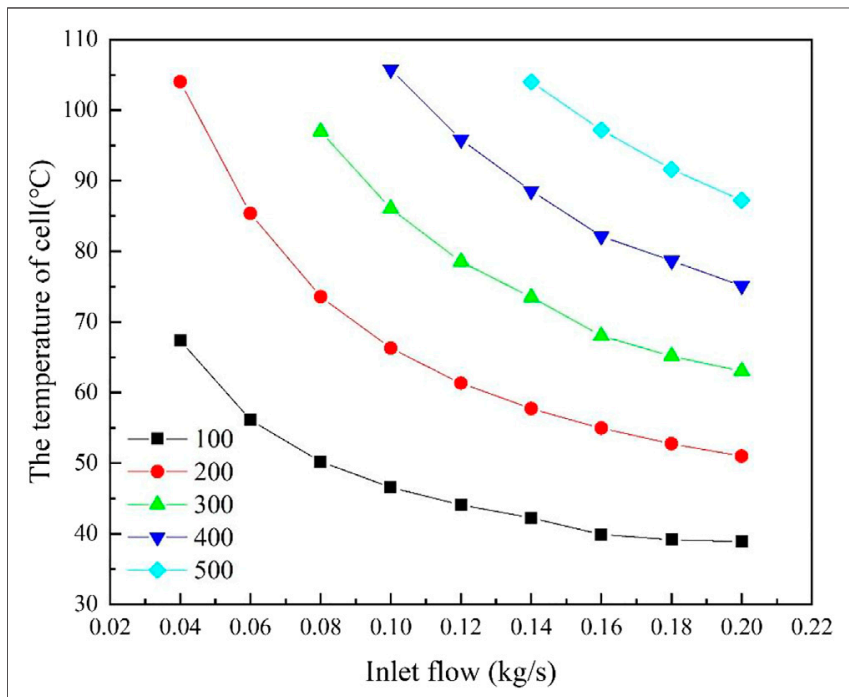

FIGURE 7 | Influence of inlet flow on the temperature of the cell.

under the single-jet nozzle is more uniform than singlechannel serpentine flow. Taking account into the uniformity of the cell temperature, the single-channel serpentine flow can be considered when the inlet flow is less than $0.1 \mathrm{~kg} / \mathrm{s}$. If the inlet flow increases, it is recommended to use the single-jet nozzle. 


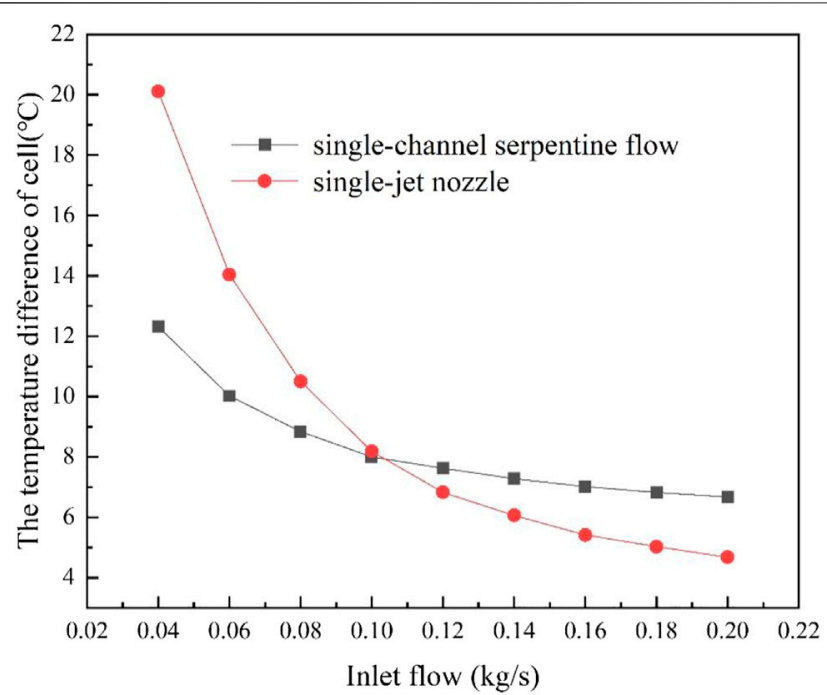

FIGURE 8 | Influence of inlet flow on the temperature uniformity of the cell.

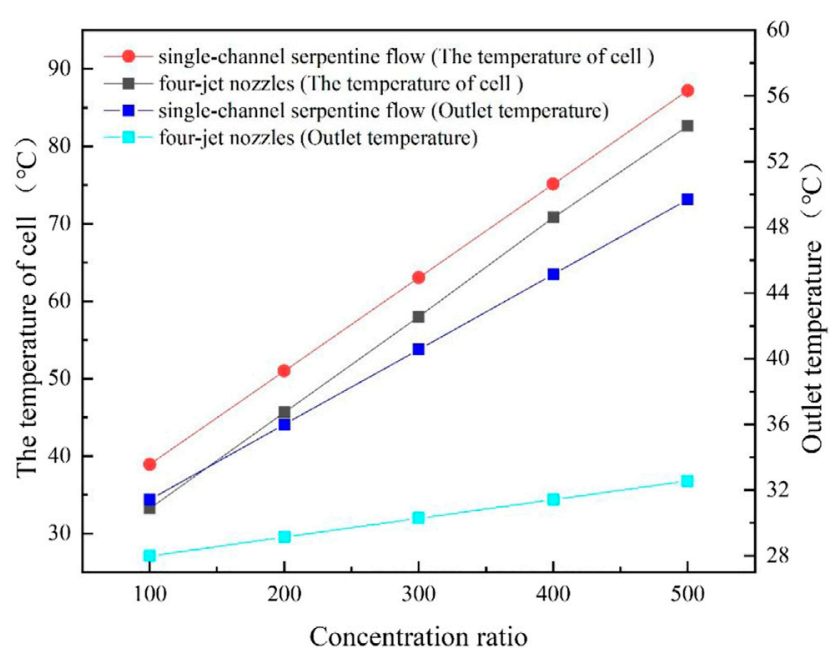

FIGURE 9 | Influence of concentration ratio on cell temperature and outlet temperature under the four-jet nozzles and single-channel serpentine flow.

\section{ANALYSIS OF TEMPERATURE UNIFORMITY AND THERMOELECTRIC CHARACTERISTICS OF CELL UNDER FOUR-JET NOZZLES}

\section{Analysis of Temperature Uniformity of Cell Under Four-Jet Nozzles}

The four-jet nozzles method is proposed for the high concentration ratio to ensure that the cell under the four-jet nozzles can not only maintain a uniform temperature field, but can also keep the overall average temperature under the high concentration ratio in the optimal temperature range.

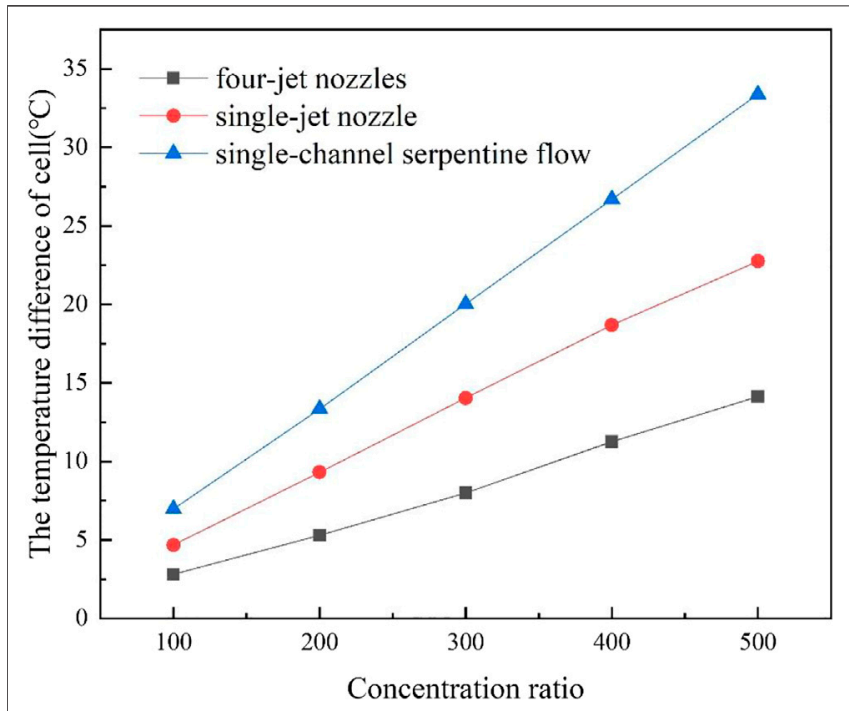

FIGURE 10 | Influence of concentration ratio on temperature uniformity of cell under the four-jet nozzles, single-channel serpentine flow, and single-jet nozzle.

Figure 9 shows the changes in the cell temperature and outlet temperature under the four-jet nozzles under different concentration ratios. The temperature of cells under the fourjet nozzles is lower than that under the single-channel serpentine flow. Both forms of heat exchange are suitable for low concentration ratios. When the concentration ratio is increased to 500, the temperature of the cell under the four-jet nozzles can be kept within the optimal operating temperature range, thereby having a stable power output.

The outlet temperature of the two heat exchange forms also increases with the increase of the concentration ratio. When the concentration ratio is relatively low, the difference in the outlet temperature of the two heat exchange forms is not large. When the concentration ratio is 500 , the outlet temperature of the single-channel serpentine flow can reach $48^{\circ} \mathrm{C}$, but the outlet temperature of the four-jet nozzles is only $32^{\circ} \mathrm{C}$. Therefore, in the high-power concentration system, the cooling effect of the singlechannel serpentine flow is worse than that of the four-jet nozzles, and the photoelectric conversion efficiency of the cell is also lower.

Figure 10 shows the change of the difference of cell temperature under the four-jet nozzles, single-channel serpentine flow, and single-jet nozzle with different concentration ratios. When the concentration ratio is relatively low, the temperature difference of the cell under the three heat exchange modes has little difference, which can be kept below $10^{\circ} \mathrm{C}$, and the cells under the three heat exchangers can maintain the temperature uniformity. As the concentration ratio increases, the temperature difference of the cell under the three heat exchange modes is significantly different. When the concentration ratio is 400 , the temperature difference of cells under the single-channel serpentine flow is the largest, exceeding $25^{\circ} \mathrm{C}$, and the temperature difference of cells under the fournozzle jet is the smallest, with a value of $10^{\circ} \mathrm{C}$. Compared with the 


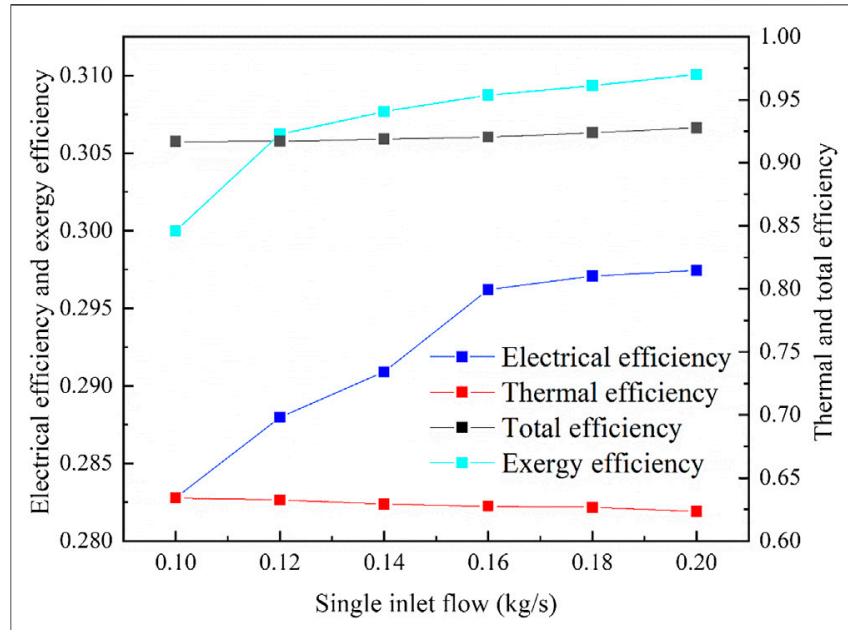

FIGURE 11 | Influence of the inlet flow on the electrical efficiency and thermal efficiency.

single-jet nozzle and the single-channel serpentine flow, the fourjet nozzles can better ensure the uniformity of the cell temperature field, which is suitable for high concentration ratios.

\section{Analysis of the Thermoelectric Performance of Cell Under Four-Jet Nozzles Total Efficiency and Exergy Efficiency of the Cell Under Four-Jet Nozzles}

Figure 11 shows the change of the electrical efficiency, thermal efficiency, total efficiency, and exergy efficiency of the cell with inlet flow under the four-jet nozzles at the concentration ratio of 500. As the inlet flow increases, the electrical efficiency, total efficiency, and exergy efficiency of cells have a rising trend, especially when the inlet flow changes from $0.1 \mathrm{~kg} / \mathrm{s}$ to $0.16 \mathrm{~kg} / \mathrm{s}$. The electrical efficiency is significantly improved, reaching 29.8\%. Thermal efficiency has little effect and remains at about $62 \%$. When the inlet flow exceeds $0.16 \mathrm{~kg} / \mathrm{s}$, the increasing trend of the electrical efficiency of the cell gradually becomes flat, which can not only maintain the stability of electrical and thermal efficiency, but also provide considerable system energy output of $31 \%$.

Influence of the Inlet Temperature of Cooling Water on Exergy Efficiency of Cell Under Four-jet nozzles Flow.

It can be seen from Figure 12 that the change of the thermal exergy efficiency and exergy efficiency of the cell under the four-jet nozzles at the concentration ratio of 500 with the inlet temperature of cooling water. Ignoring the influence of external radiation, it is assumed that the ambient temperature in summer is $20^{\circ} \mathrm{C}$ and the ambient temperature in winter is $0^{\circ} \mathrm{C}$. The thermal exergy efficiency and total exergy efficiency in winter are significantly higher than that in summer. When the inlet temperature of cooling water is $60^{\circ} \mathrm{C}$, the thermal exergy efficiency in winter can exceed $10 \%$, and the total efficiency can exceed $40 \%$. From the comparison between winter and summer, a higher energy quality can be obtained in winter.

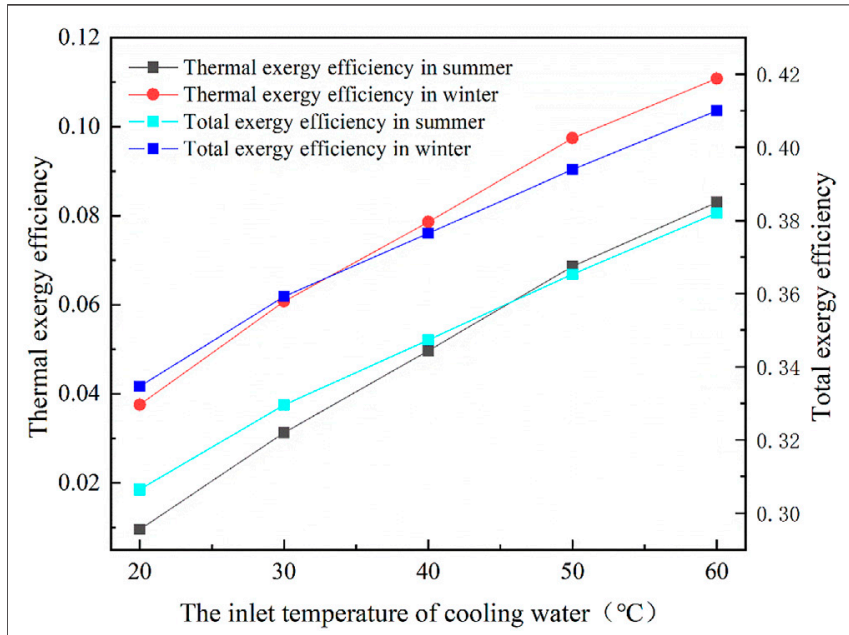

FIGURE 12 | Inlet temperature of cooling water on the thermal exergy efficiency and exergy efficiency of the cell under the four-jet nozzles in summer and winter.

\section{CONCLUSION}

Due to the uneven energy flow density at high concentration of solar concentrators, it is of great significance to maintain cell temperature uniformity. Based on high-power concentrated energy flow density, this study establishes a thermoelectric model of concentrated solar energy, which uses four forms, namely single-channel serpentine flow, multi-channel flat plate, full jet, and single-jet nozzle. In this model, the uniformity of the cell temperature field and the thermoelectric performance are extensively analyzed.

1) Considering the uniformity of the temperature field, the cell under the multi-channel plate is the worst, which distributed in stripes. The cell under the single-channel serpentine flow is relatively uniform. Both the full jet and the single-jet nozzle can maintain temperature uniformity under the high-power concentrated energy flow density, but the uniformity of the single-jet nozzle is better than that of the full jet. The single-channel serpentine flow and single-jet nozzle can better maintain the uniformity of the cell temperature field.

2) As the flow rate increases, the temperature of the cell has a downward trend, but as the concentration ratio increases, the range of the flow rate to ensure that the temperature of cell is in a safe area will decrease. For single-jet nozzle, when the concentration ratio exceeds 500, it is not enough to ensure the effective working temperature and temperature uniformity of the cell. However, when the concentration ratio is 500 , the single-channel serpentine flow can work normally. Therefore, the single-channel serpentine flow is more suitable for high-power concentration systems than single-jet nozzle. Considering the uniformity of the cell temperature, when the inlet flow rate is less than $0.1 \mathrm{~kg} / \mathrm{s}$, the single-channel serpentine flow can be considered. If the 
inlet flow increases, it is recommended to use the single-jet nozzle.

3) In order to maintain the uniformity of the cell temperature when the high-power concentrated energy flow density is uneven, a four-jet nozzles heat exchange form is proposed and analyzed. When the concentration ratio is increased to 500, the temperature of cell under the four-jet nozzles can be kept within the optimal operating temperature range, thereby having a stable power output. Compared with the single-jet nozzle and the single-channel serpentine flow, the four-jet nozzles can better ensure the uniformity of the cell temperature field, which is suitable for high concentration ratios.

4) At an energy flow density of the concentration ratio of 500, as the inlet flow increases, the electrical efficiency is significantly improved to $29.8 \%$. The thermal efficiency has little effect and remains at about $62 \%$. Taking into account the quality of heat and electricity, the total exergy efficiency has not changed much, basically maintained at about $31 \%$. The thermal exergy efficiency and total exergy efficiency in winter are significantly higher than that in summer. When the inlet temperature of cooling water is $60^{\circ} \mathrm{C}$, the thermal exergy efficiency in winter can exceed $10 \%$,

\section{REFERENCES}

Abo-Zahhad, E. M., Ookawara, S., Radwan, A., El-Shazly, A. H., and Elkady, M. F., 2019. Numerical Analyses of Hybrid Jet Impingement/microchannel Cooling Device for thermal Management of High Concentrator Triple-junction Solar Cell, Appl. Energ. 253. doi:10.1016/j.apenergy.2019.113538

Abo-Zahhad, E. M., Ookawara, S., Radwan, A., El-Shazly, A. H., and ElKady, M. F., 2018. Thermal and Structure Analyses of High Concentrator Solar Cell under Confined Jet Impingement Cooling, Energ. Convers. Management 176, 39-54. doi:10.1016/j.enconman.2018.09.005

Al-Shamani, A. N., Yazdi, M. H., Alghoul, M. A., Abed, A. M., Ruslan, M. H., Mat, S., et al. 2014. Nanofluids for Improved Efficiency in Cooling Solar Collectors A Review, Renew. Sustainable Energ. Rev. 38, 348-367. doi:10.1016/ j.rser.2014.05.041

Aldossary, A., Mahmoud, S., and AL-Dadah, R., 2016, Technical Feasibility Study of Passive and Active Cooling for Concentrator PV in Harsh Environment, Appl. Therm. Eng., 100, 490-500. doi:10.1016/j.applthermaleng.2016.02.023

Arvanitis, K. D., Papanicolaou, E., Mathioulakis, E., Belessiotis, V., and Bouris, D., 2020. Experimental Evaluation of Flat-Plate Heat Absorbers for MediumTemperature Linear-Focus Solar Systems: Composite U-Bends vs Straight Rectangular-Multi-Channels, Appl. Therm. Eng. 175, 115364. doi:10.1016/ j.applthermaleng.2020.115364

Aste, N., Leonforte, F., and Del Pero, C. , 2015. Design, Modeling and Performance Monitoring of a Photovoltaic-thermal (PVT) Water Collector, Solar Energy 112, 85-99. doi:10.1016/j.solener.2014.11.025

Deng, T., Zhang, G., and Ran, Y. , 2018. Study on thermal Management of Rectangular Li-Ion Battery with Serpentine-Channel Cold Plate, Int. J. Heat Mass Transfer 125, 143-152. doi:10.1016/j.ijheatmasstransfer.2018.04.065

Dirker, J., Juggurnath, D., Kaya, A., Osowade, E. A., Simpson, M., Lecompte, S., et al. 2019. Thermal Energy Processes in Direct Steam Generation Solar Systems: Boiling, Condensation and Energy Storage - A Review, Front. Energ. Res. 6. doi:10.3389/fenrg.2018.00147

Fernández, E. F., Almonacid, F., Rodrigo, P., and Pérez-Higueras, P., 2014. Calculation of the Cell Temperature of a High Concentrator Photovoltaic (HCPV) Module: A Study and Comparison of Different Methods, Solar Energ. Mater. Solar Cell 121, 144-151. doi:10.1016/j.solmat.2013.11.009 and the total efficiency can exceed $40 \%$, which can obtain high-quality heat output.

\section{DATA AVAILABILITY STATEMENT}

The original contribution presented in the study are included in the article/supplementary material, further inquiries can be directed to the corresponding author.

\section{AUTHOR CONTRIBUTIONS}

HC conceived the conceptualization and methodology. YW and YD conducted the normal analysis and writing. $\mathrm{BC}$ performed the data curation and visualization. JY conducted the review and editing. All authors contributed to the article and approved the submitted version.

\section{FUNDING}

This research is supported by the National Natural Science Foundation of China (No. 51906020).

Gakkhar, N., Soni, M. K., and Jakhar, S., 2020. Experimental and Theoretical Analysis of Hybrid Concentrated Photovoltaic/thermal System Using Parabolic Trough Collector, Appl. Therm. Eng. 171, 115069. doi:10.1016/ j.applthermaleng.2020.115069

Habibollahzade, A., Gholamian, E., Ahmadi, P., and Behzadi, A., 2018. Multicriteria Optimization of an Integrated Energy System with Thermoelectric Generator, Parabolic Trough Solar Collector and Electrolysis for Hydrogen Production, Int. J. Hydrogen Energ. 43, 14140-14157. doi:10.1016/ j.ijhydene.2018.05.143

Hajabdollahi, H., 2021. Thermoeconomic Assessment of Integrated Solar Flat Plat Collector with Cross Flow Heat Exchanger as Solar Air Heater Using Numerical Analysis, Renew. Energ. 168, 491-504. doi:10.1016/j.renene.2020.12.080

He, R.-f., Zhong, M. R., and Huang, J. B., 2021. The Dynamic Effects of RenewableEnergy and Fossil-Fuel Technological Progress on Metal Consumption in the Electric Power Industry, Resour. Pol. 71, 101985. doi:10.1016/ j.resourpol.2021.101985

Hernandez-Perez, J. G., Carrillo, J. G., Bassam, A., Flota-Banuelos, M., and PatinoLopez, L. D., 2021. Thermal Performance of a Discontinuous Finned Heatsink Profile for PV Passive Cooling, Appl. Therm. Eng. 184, 116238. doi:10.1016/ j.applthermaleng.2020.116238

Khanjari, Y., Pourfayaz, F., and Kasaeian, A. B. , 2016. Numerical Investigation on Using of Nanofluid in a Water-Cooled Photovoltaic thermal System, Energ. Convers. Management 122, 263-278. doi:10.1016/j.enconman.2016.05.083

Kumar, R., Kharub, M., Kumar, V., and Varun, fnm. , 2021. Heat Augmented Due to Array of Protrusions on Absorber Plate in Solar Heat Exchanger, Mater. Today Proc. 38, 2425-2430. doi:10.1016/j.matpr.2020.07.384

Lakshmi Swarupa, M., Vijay Kumar, E., and Sreelatha, K. , 2021. Modeling and Simulation of Solar PV Modules Based Inverter in MATLAB-SIMULINK for Domestic Cooking, Mater. Today Proc. 38, 3414-3423. doi:10.1016/ j.matpr.2020.10.835

Leonard, M. D., Michaelides, E. E., and Michaelides, D. N. , 2020. Energy Storage Needs for the Substitution of Fossil Fuel Power Plants with Renewables, Renew. Energ. 145, 951-962. doi:10.1016/j.renene.2019.06.066

Li, G., Lu, Y., Xuan, Q., Akhlaghi, Y. G., Pei, G., Ji, J., et al. 2020. Small Scale Optimization in Crystalline Silicon Solar Cell on Efficiency Enhancement of Low-Concentrating Photovoltaic Cell, Solar Energy 202, 316-325. doi:10.1016/ j.solener.2020.03.094 
Liang, K., Zhang, H., Chen, H., Gao, D., and Liu, Y., 2021. Design and Test of an Annular Fresnel Solar Concentrator to Obtain a High-Concentration Solar Energy Flux, Energy 214. doi:10.1016/j.energy.2020.118947

Maka, A. O. M., and O'Donovan, T. S., 2020. A Review of thermal Load and Performance Characterisation of a High Concentrating Photovoltaic (HCPV) Solar Receiver Assembly, Solar Energy 206, 35-51. doi:10.1016/ j.solener.2020.05.022

Nadda, R., Kumar, A., and Maithani, R. , 2018. Efficiency Improvement of Solar Photovoltaic/solar Air Collectors by Using Impingement Jets: A Review, Renew. Sustainable Energ. Rev. 93, 331-353. doi:10.1016/j.rser.2018.05.025

Parupudi, R. V., Singh, H., and Kolokotroni, M., 2020. Low Concentrating Photovoltaics (LCPV) for Buildings and Their Performance Analyses, Appl. Energ. 279, 115839. doi:10.1016/j.apenergy.2020.115839

Qeays, I. A., Yahya, S. M., Asjad, M., and Khan, Z. A., 2020. Multi-performance Optimization of Nanofluid Cooled Hybrid Photovoltaic thermal System Using Fuzzy Integrated Methodology, J. Clean. Prod. 256. doi:10.1016/j.jclepro.2020.120451

Saura, J. M., Rodrigo, P. M., Almonacid, F. M., Chemisana, D., and Fernández, E. F., 2021. Experimental Characterisation of Irradiance and Spectral Nonuniformity and its Impact on Multi-junction Solar Cells: Refractive vs. Reflective Optics, Solar Energ. Mater. Solar Cell 225. doi:10.1016/ j.solmat.2021.111061

Shanks, K., Ferrer-Rodriguez, J. P., Fernández, E. F., Almonacid, F., PérezHigueras, P., Senthilarasu, S., et al. , 2018. A >3000 Suns High Concentrator Photovoltaic Design Based on Multiple Fresnel Lens Primaries Focusing to One central Solar Cell, Solar Energy 169, 457-467. doi:10.1016/j.solener.2018.05.016

Siah Chehreh Ghadikolaei, S., 2021. Solar Photovoltaic Cells Performance Improvement by Cooling Technology: An Overall Review, Int. J. Hydrogen Energ. 46, 10939-10972. doi:10.1016/j.ijhydene.2020.12.164

Singh, R., 2021. Solar-city Plans with Large-Scale Energy Storage: Metrics to Assess the Ability to Replace Fossil-Fuel Based Power, Sustainable Energ. Tech. Assessments 44. doi:10.1016/j.seta.2021.101065
Sun, Q., Lin, D., Khayatnezhad, M., and Taghavi, M. , 2021. Investigation of Phosphoric Acid Fuel Cell, Linear Fresnel Solar Reflector and Organic Rankine Cycle Polygeneration Energy System in Different Climatic Conditions, Process Saf. Environ. Prot. 147, 993-1008. doi:10.1016/ j.psep.2021.01.035

Wang, Y. N., Lin, T. T., Leong, J. C., Hsu, Y. T., Yeh, C. P., Lee, P. H., et al. , 2013. Numerical Investigation of High-Concentration Photovoltaic Module Heat Dissipation, Renew. Energ. 50, 20-26. doi:10.1016/ j.renene.2012.06.016

Xinxin, G., Heng, Z., Haiping, C., Kai, L., Jiguang, H., and Haowen, L., 2019. Experimental and Theoretical Investigation on a Hybrid LCPV/T Solar Still System, Desalination 468, 114063. doi:10.1016/j.desal.2019.07.003

Xu, R., Ma, Y., Yan, M., Zhang, C., Xu, S., and Wang, R. , 2018. Effects of Deformation of Cylindrical Compound Parabolic Concentrator (CPC) on Concentration Characteristics, Solar Energy 176, 73-86. doi:10.1016/ j.solener.2018.10.001

Zheng, D., Wang, J., Chen, Z., Baleta, J., and Sundén, B., 2020. Performance Analysis of a Plate Heat Exchanger Using Various Nanofluids, Int. J. Heat Mass Transfer 158, 119993. doi:10.1016/j.ijheatmasstransfer.2020.119993

Conflict of Interest: The authors declare that the research was conducted in the absence of any commercial or financial relationships that could be construed as a potential conflict of interest.

Copyright (c) 2021 Chen, Wang, Ding, Cai and Yang. This is an open-access article distributed under the terms of the Creative Commons Attribution License (CC BY). The use, distribution or reproduction in other forums is permitted, provided the original author(s) and the copyright owner(s) are credited and that the original publication in this journal is cited, in accordance with accepted academic practice. No use, distribution or reproduction is permitted which does not comply with these terms. 


\section{GLOSSARY}

$\boldsymbol{A}$ the area of the entire surface $\left[\mathrm{m}^{2}\right]$

$A_{p v}$ the area of the photovoltaic cell $\left[\mathrm{m}^{2}\right]$

$\boldsymbol{c}_{\boldsymbol{p}}$ the specific heat capacity of the cooling fluid at constant pressure $\left[\mathrm{J} \cdot \mathrm{kg}^{-1} \cdot \mathrm{C}^{-1}\right]$

$\boldsymbol{E}_{\boldsymbol{p} v}$ the power output of the photovoltaic cell [W]

$\boldsymbol{G}$ the total energy reaching the surface of the photovoltaic cell $\left[\mathrm{W} \cdot \mathrm{m}^{-2}\right]$

$\boldsymbol{m}$ the mass flow of cooling fluid $\left[\mathrm{kg} \cdot \mathrm{s}^{-1}\right]$

$\boldsymbol{Q}_{\boldsymbol{p} v}$ the thermal energy generated by the photovoltaic cell in the process of absorbing solar energy [W]

$\boldsymbol{Q}_{w}$ the heat energy output by the system [W]

$\boldsymbol{r}_{\boldsymbol{p} v}$ the coverage factor of photovoltaic cells [\%]

$\boldsymbol{T}_{\text {cell }}$ the working temperature of photovoltaic cell [ $\left.{ }^{\circ} \mathrm{C}\right]$
$\boldsymbol{T}_{\boldsymbol{r} e f}$ the temperature of the photovoltaic cell under reference conditions [ $\left.{ }^{\circ} \mathrm{C}\right]$

$\boldsymbol{T}_{\text {out }}$ the outlet temperature of the cooling fluid [K]

$\boldsymbol{T}_{\boldsymbol{s}}$ the temperature of the environment [K]

$\boldsymbol{t}_{\text {in }}$ the inlet temperature of the cooling fluid [ $\left.{ }^{\circ} \mathrm{C}\right]$

$\boldsymbol{t}_{\text {out }}$ the outlet temperature of the cooling fluid [ $\left.{ }^{\circ} \mathrm{C}\right]$

$\boldsymbol{\alpha}_{\boldsymbol{p} v}$ the absorption rate of the photovoltaic cell [\%]

$\boldsymbol{\beta}$ the thermal coefficient [\%]

$\boldsymbol{\eta}_{\boldsymbol{p} \boldsymbol{v}}$ the photoelectric conversion efficiency of photovoltaic cells [\%]

$\boldsymbol{\eta}_{\boldsymbol{r} \text { ef }}$ the electrical efficiency of the photovoltaic cell under reference conditions [\%]

$\boldsymbol{\eta}_{\boldsymbol{t} \boldsymbol{h}}$ the thermal efficiency of the photovoltaic cell [\%]

$\boldsymbol{\eta}_{\boldsymbol{e l}}$ the exergy efficiency of the photovoltaic cell [\%] 